Volume 1 Nomor 1, November 2020: h. 1 - 13

P-ISSN: 2722-4465, E-ISSN: 2746-8151

Creative Commons Attribution-NonCommercial 4.0 International

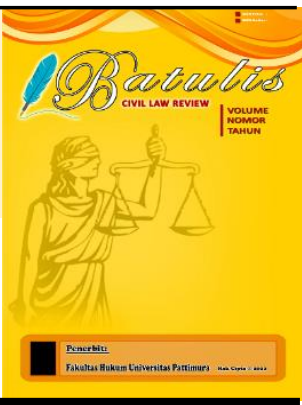

\title{
Penerapan Prinsip Character Dalam Pelaksanaan Prinsip Kehati- hatian pada Analisis Pemberian Kredit Usaha Mikro
}

\author{
Rahmadi Indra Tektona ${ }^{1 *}$, Qori'atur Risma ${ }^{2}$ \\ 1,2 Fakultas Hukum Universitas Jember, Jember, Indonesia. \\ *E-mail: rahmadiindra@unej.ac.id
}

\begin{tabular}{l}
\multicolumn{1}{c}{ Dikirim: $28 / 05 / 2020$} \\
\hline Info Artikel \\
\hline Keywords: \\
Factors; Character; Credit \\
\hline Kata Kunci: \\
Faktor; Karakter; Kredit
\end{tabular}

Direvisi: $18 / 08 / 2020$

Dipublikasi: 30/10/2020

\begin{abstract}
Credit is the ability to carry out a purchase or make a loan with a promise that payment will be deferred at an agreed time period. One financial institution that can provide credit is the bank, when providing credit the bank not only uses its own capital but also uses the customer's funds that have been entrusted to the bank. When providing credit, the bank cannot avoid the risk of non-performing loans, related to this, the bank applies the precautionary principle that is realized by the existence of the 5C principle, one of which is character. The application of the character principle aims to assess the character or character of the prospective debtor, whether the prospective debtor has a good character or is not good. The purpose of this paper is to analyze the factors driving and inhibiting the implementation of character principles in the analysis of micro business credit as a form of implementing prudential principles at Bank Mandiri Jember Branch. The type of research used by the author is Empirical Juridical. Then the method used is a qualitative approach method. The results of this research are the driving factors consisting of several factors, among others, in order to make credit activities run safely, minimize losses, ensure the smooth delivery of credit facilities, and build cooperation and trust between banks and customers for a long period of time. Related to the inhibiting factors consist of non-cooperative customers, bad faith in bank management, human resources, and proximity.
\end{abstract}

\begin{tabular}{l}
\hline Abstrak \\
Kredit adalah kemampuan untuk melakukan pembelian atau \\
melakukan pinjaman dengan janji pembayaran akan \\
ditangguhkan pada jangka waktu yang disepakati. Salah satu \\
lembaga keuangan yang dapat memberikan kredit adalah bank, \\
dalam memberikan kredit bank tidak hanya menggunakan \\
modal sendiri tetapi juga menggunakan dana nasabah yang \\
telah dititipkan kepada bank. Dalam memberikan kredit, bank \\
tidak dapat menghindari risiko kredit bermasalah, terkait hal \\
tersebut bank menerapkan prinsip kehati-hatian yang \\
diwujudkan dengan adanya prinsip 5C yang salah satunya \\
adalah karakter. Penerapan prinsip karakter bertujuan untuk \\
menilai karakter atau karakter calon debitur, apakah calon \\
debitur memiliki karakter yang baik atau kurang baik. Tujuan \\
penulisan ini adalah untuk menganalisis faktor-faktor
\end{tabular}


DOI:

10.47268/ballrev.v1i1.420 pendorong dan penghambat penerapan prinsip karakter dalam analisis kredit usaha mikro sebagai bentuk penerapan prinsip kehati-hatian pada Bank Mandiri Cabang Jember. Jenis penelitian yang digunakan penulis adalah Yuridis Empiris. Kemudian metode yang digunakan adalah metode pendekatan kualitatif. Hasil dari penelitian ini adalah faktor pendorong yang terdiri dari beberapa faktor antara lain agar kegiatan perkreditan berjalan dengan aman, meminimalisir kerugian, menjamin kelancaran penyaluran fasilitas kredit, dan membangun kerjasama dan kepercayaan antara bank dengan nasabah dalam jangka waktu yang lama. waktu. Terkait dengan faktor penghambat terdiri dari nasabah non koperasi, itikad buruk terhadap pengelolaan bank, sumber daya manusia, dan kedekatan.

\section{Pendahuluan}

Bank biasa disebut dengan financial intermediary (Wilardjo, 2014: 1), sebagai lembaga keuangan bank memiliki aset fiansial yang menjadi aset terbesarnya sedangkan dengan besarnya aset yang dimiliki maka aktifa tetapnya akan menjadi kecil (Sari, 2013: 933). Pada berkembangnya dunia perbankan sekarang ini mulai bermunculan perbankan dengan prinsip syariah atau ajaran Islam. Kegiatan bank syariah tidak mengandung unsur riba, maisir, gharar, haram, dan zalim yang mana dapat merugikan nasabah (Usman, 2012: 116). Bank syariah sangat menjunjung tinggi prinsip transparansi, keadilan, dan ajaran Islam (Yuspin, 2016: 24). Sebagai salah satu lembaga keuangan yang memiliki suatu nilai yang strategis dalam kehidupan sebuah negara, maka lembaga perbankan mempunyai posisi yang sangat penting guna mengatur keuangan. Industri perbankan dituntut untuk selalu dapat menciptakan pertumbuhan ekonomi yang meningkat dan berkembang, guna meningkatkan taraf hidup masyarakat maka dari itu bank menghimpun dana dari masyarakat dan disalurkan kembali kepada masyarakat.

Tidak cukup dengan melakukan kegiatan menghimpun dan menyalurkan dana tetapi juga mempunyai tujuan yang jelas demi pembangunan nasional, meningkatkan pemerataan, pertumbuhan ekonomi, dan stabilitas nasional yang merupakan sasaran perbankan dalam menjalankan fungsinya (Mgs. The' Aman, 1989: 3). Pembangunan ekonomi suatu negara bergantung pada berkembangan dan kontribusi dari perbankan, sebab apabila kondisi perbankan memburuk maka akan berakibat pula kepada perekonomian Negara (Pratama, 2010: 1), tidak cukup dengan melakukan kegiatan menghimpun dan menyalurkan dana tetapi juga mempunyai tujuan yang jelas demi pembangunan nasional, meningkatkan pemerataan, pertumbuhan ekonomi, dan stabilitas nasional yang merupakan sasaran perbankan dalam menjalankan fungsinya (Mgs. The'Aman, 1989: 3). Selain melakukan kegitan penghimpunan dana dan menyalurkannya kembali, bank juga merupakan badan yang tugas utamanya menciptakan kredit. Saat menjalankan perannya bank bertindak sebagai salah satu dari lembaga keuangan yang memberikan kredit dan jasa lainnya. Kredit juga merupakan kegiatan yang dapat memberikan sumbangan pendapatan yang besar bagi bank, oleh karena itu bank secara terus menerus memberikan kredit demi kesinambungan operasionalnya.

Kredit dibedakan berdasarkan jangka waktunya, kegunaannya, pemakaiannya, dan sektor yang dibiayai (Supramono, 1996: 45). Pada umumnya masyarakat mengartikan kredit sebagai hutang yang pada jangka waktu tertentu harus di bayar lunas (Mgs. The' Aman, 1989: 44). Bank dalam memberikan kredit menggunakan dana yang berasal dari modal sendiri, 
dana yang dipercayakan pada bank tersebut, serta memperedarkan alat pembayaran baru berupa uang giral (Simorangkir, 1989: 33). Saat pelaksanaan memberikan kredit bank menggunakan dana dari masyarakat sehingga dapat memberikan resiko yang besar, diperlukannya kehati- hatian ketika memberikan kredit. Salah satu resiko yang akan terjadi adalah Non- Performing Loan, yakni sebuah kondisi dimana kredit tidak kembali secara tepat waktu. Sehingga dibutuhkan pengelolaan kredit yang baik dan memperhatikan prinsipprinsip perbankan yang ada. Saat kredit dikelola dengan baik dan menerapkan prinsipprinsip yang ada maka akan dapat meminimalisir resiko kerugian yang akan ditanggung oleh pihak bank.

Sebagai contoh terdapat kasus kredit dimana ada seorang pria bernama Hermawan yang beralamatkan di Kecamatan Arjasa Kabupaten Jember mengajukan kredit yang akan digunakan untuk menjalankan usaha mikro sebesar 60 juta rupiah kepada Bank Mandiri Cabang Jember dengan jangka waktu 24 bulan. Permasalahan yang terjadi adalah bahwa pak Hermawan sering tidak tepat waktu dalam membayar angsuran kredit, pak Hermawan dinilai tidak memiliki itikad baik dalam mematuhi pembayaran angsuran kredit. Sehingga dapat ditarik kesimpulan bahwa karakter debitur kurang baik. Saat seorang debitur meminjam dana terhadap pihak bank, maka pihak bank tidak semerta-merta akan langsung memberikan dana tersebut. Sebab ketika akan memberikan kredit kepada seorang debitur maka pihak perbankan akan menerapkan prinsip-prinsip 5C guna meminimalisir kerugian. 5C merupakan prinsip yang harus dilakukan terlebih dahulu oleh pihak bank manakala akan memberikan kredit kepada debitur, penerapan prinsip ini juga dapat menunjukan bahwasannya bank tersebut dalam keadaan sehat sebab mampu menjalankan perkreditan dengan menjadikan prinsip 5C tersebut sebagai pedomannya. Prinsip 5C merupakan singkatan dari character, capacity, capital, collateral, dan Condition of Economic.

Berdasarkan uraian di atas, rumusan masalah yang diangkat pertama, Apa faktor penghambat dan pendorong pelaksanaan dari prinsip character dalam analisis pemberian kredit usaha mikro sebagai bentuk pelaksanaan prinsip kehati-hatian pada PT Bank Mandiri Cabang Jember. Tujuan penulisan ini guna menganalisis faktor pendorong dan penghambat pelaksanaan prinsip character dalam analisis pemberian kredit usaha mikro sebagai bentuk pelaksanaan prinsip kehati-hatian pada Bank Mandiri Cabang Jember.

\section{Metode Penelitian}

Metode penelitian yang digunakan Penulis adalah Yuridis Empiris. Kemudian metode yang digunakan adalah metode pendekatan kualitatif. Sedangkan untuk sumber data terdiri dari: a.) sumber data primer yaitu hasil wawancara; b.) sumber data sekunder meliputi bukubuku hukum, jurnal hukum dan karya ilmiah di bidang hukum. Dalam mengumpulkan sumber data primer, penulis menggunakan teknik random sampling. Sedangkan teknik pengumpulan data, penulis menggunakan teknik wawancara dan studi dokumentasi. Teknik analisis data yang digunakan dalam penelitian ini adalah menggunakan pendekatan kualitatif dengan metode analisis deskriptif.

\section{Hasil dan Pembahasan}

Terdapat kasus kredit dimana ada seorang pria bernama Hermawan yang beralamatkan di Kecamatan Arjasa Kabupaten Jember mengajukan kredit yang akan digunakan untuk menjalankan usaha mikro sebesar 60 juta rupiah kepada Bank Mandiri Cabang Jember dengan jangka waktu 24 bulan. Permasalahan yang terjadi adalah bahwa pak Hermawan 
sering tidak tepat waktu dalam membayar angsuran kredit, pak Hermawan dinilai tidak memiliki itikad baik dalam mematuhi pembayaran angsuran kredit. Sebelumnya telah disepakati perjanjian mengenai jatuh tempo angsuran untuk segera dibayarkan kepada pihak bank, dalam hal ini pak Hermawan tidak menepati kesepakatan perjajanjian yang telah dibuat. Perjanjian kredit diatur dalam Pasal 1 ayat 11 Undang-Undang Nomor 10 Tentang Perubahan Atas Undang-undang Nomor 7 tahun 1992 Tentang Perbankan. Pasal tersebut menyebutkan bahwa penyediaan uang atau tagihan berdasarkan persetujuan atau kesepakatan pinjam meminjam antara bank dengan pihak lain, dalam perjanjian ini juga tertera mengenai jatuh tempo pelunasan serta jatuh tempo pembayaran angsuran. Perbuatan yang dilakukan oleh pak Hermawan dapat ditarik kesimpulan bahwa karakter debitur kurang baik.

Menurut Maya dan Riska sebagai mikro kredit sales sebagai mikro kredit analisis di Kantor Bank Mandiri Cabang Jember (Wawancara: Tanggal 6 Januari 2020) bahwa Kredit tidak dibayarkan tepat waktu sudah dapat dikategorikan sebagai kredit bermasalah, kondisi ini akan memberikan dampak kerugian bagi pihak perbankan. Kredit bermasalah memberikan dampak terhadap kinerja bank antara lain terjadinya ketidaklancaran perputaran arus kas, apabila hal ini terus berlanjut maka pihak bank tidak akan dapat memberikan kredit kepada nasabah dalam jumlah yang besar. Selain itu akibat dari kredit bermasalah adalah laba bank akan menurun. Guna meminimalisir terjadinya kredit bermasalah maka pihak perbankan memiliki prinsip kehati-hatian yang diatur didalam Pasal 2 Undang-Undang Nomor 10 tahun 1998 Tentang Perubahan Atas Undang-undang Nomor 7 Tahun 1992 Tentang Perbankan. Prinsip kehati-hatian merupakan prinsip yang penting dalam pengelolaan sistim perbankan yang cenderung beresiko (Wardani, P. D. K. et al. 2013: 5). Pada praktiknya prinsip kehati-hatian diwujudkan dengan adanya prinsip 5C yaitu character, capacity, collateral, condition of economic, dan capital. Prinsip 5C adalah wujud dari prinsip kehati-hatian yang merupakan langkah untuk meminimalisir kredit bermasalah. Prinsip ini akan menjadi tolak ukur bank ketika hendak memberikan kredit, prinsip ini merupakan suatu tindakan yang penting untuk dilakukan ketika akan memberikan kredit kepada debitur guna melihat layak atau tidaknya debitur diberikan kredit (Jusuf, 1995: 195). Kredit bermasalah disebabkan oleh tidak dibayarkannya kredit secara tepat waktu, hal ini dapat disebabkan dari segi usaha debitur yang memang sedang mengalami hambatan sehingga tidak dapat membayar kredit sesuai waktu yang telah disepakati ataupun memang debitur tersebut memiliki itikad untuk sengaja menunda pembayaran (Wahyuni, 2018: 53).

Guna dapat meminimalisir debitur yang memiliki itikad tidak baik maka diperlukan analisis character untuk mengetahui apakah debitur tersebut memiliki character yang baik ataukah tidak. Character adalah salah satu dari prinsip 5C yang harus dilakukan oleh pihak bank ketika akan memberikan kredit kepada calon debitur, prinsip character merupakan langkah yang penting untuk dilakukan oleh pihak bank. Character itu sendiri adalah meyakini bahwa sifat atau kepribadian seseorang benar-benar dapat dipercaya dan hal ini dapat dicerminkan dari latar belakangnya. Tujuan dari penerapan prinsip character ini bahwa pihak bank dapat mengetahui itikad dari calon debitur yang akan mengajukan pinjaman apakah benar-benar baik atau kurang baik, sehingga jika didapati itikad yang kurang baik maka bank akan lebih mempertimbangkan bahkan bisa jadi tidak akan merealisasikan pengajuan pinjaman tersebut (Thamrin \& Tantri, 2012: 173).

Semua orang baik itu perseorangan atau kelompok pasti memiliki kebutuhan, dan kebutuhan itu sendiri sifatnya ada dua macam yakni kebutuhan mendesak dan kebutuhan tidak mendesak. Pemenuhan atas kebutuhan itu sendiri berkaitan dengan masalah dana, terlebih besar nominal yang dibutuhkan tidak sedikit sehingga dana yang dimiliki seringkali 
tidak mencukupi sehingga salah satu jalan keluar yaitu dengan cara berhutang ke pihak lain seperti contohnya pihak bank (Yunita, 2019: 44). Pasal 1 ayat 2 Undang-Undang Nomor 10 Tahun 1998 Tentang Perubahan Atas Undang-undang Nomor 7 Tahun 1992 Tentang Perbankan bahwa Pebankan memiliki peranan penting dalam perkembangan perekonomian suatu negara guna meningkatkan taraf kehidupan serta pemerataan perekonomian masyarakat, hal itu diwujudkan dengan tujuan perbankan dalam meningkatkan taraf hidup dan pemerataan ekonomi sesuai peraturan perundang-undangan bahwa bank melakukan penghimpunan dana dan menyalurkannya kembali kepada masyarakat.

Saat menjalankan usahanya bank umum diawasi oleh bank sentral yang bertindak sebagai bankers bank pimpinan yang mendorong serta mengawasi semua bank yang ada (Djumhana, 1993: 107). Bank merupakan salah satu sumber utama bagi masyarakat yang sedang membutuhkan dana maupun yang ingin meningkatkan konsumsinya sebab bank dapat memberikan kredit bagi perorangan maupun badan usaha dari kegiatan penghimpunan dana lalu disalurkan kembali dalam bentuk perkreditan. Selain melakukan kegitan penghimpunan dana dan menyalurkannya kembali, bank juga merupakan badan yang tugas utamanya menciptakan kredit (Suyatno, 1990: 12). Saat menjalankan perannya bank bertindak sebagai salah satu dari lembaga keuangan yang memberikan kredit dan jasa lainnya (Simorangkir, 1989: 33).

Pasal 1 Ayat 11 Undang-undang Nomor 10 Tahun 1998 Tentang Perubahan Atas Undang-undang Nomor 7 Tahun 1992 Tentang Perbankan bahwa Kredit adalah penyediaan uang atau tagihan yang dapat dipersamakan dengan itu, berdasarkan persetujuannya atau kesepakatan pinjam-meminjam antara bank dengan pihak lain yang mewajibkan pihak peminjam untuk melunasi hutangnya setelah jangka waktu tertentu dengan pemberian bunga. Pada umumnya masyarakat mengartikan kredit sebagai hutang yang harus dibayarkan. Kredit itu sendiri merupakan pembayaran yang tidak tunai, dimana pembayarannya ditangguhkan dalam waktu tertentu sesuai yang telah disepakati secara bersama antara debitur dengan kreditur. Kredit adalah suatu kesepakatan pinjammeminjam antara kreditur dengan debitur, dimana pihak debitur diwajibkan untuk melunasi pinjaman tersebut sesuai dengan waktu yang telah disepakati dengan pemberian bunga. Orang yang mendapatkan kredit berarti telah mendapatkan kepercayaan dari pihak pemberi kredit, dengan kata lain bahwa pemberi kredit percaya kredit yang diberikan sekarang akan dapat dikembalikan oleh penerima kredit pada waktu tertentu yang telah ditentukan. Pada praktiknya, kredit memberikan sumbangan terbesar bagi pihak bank, oleh karena itu kegiatan kredit secara terus menerus akan tetap dilakukan.

Kredit memiliki tujuan untuk mengembangkan pembangunan dengan menggunakan prinsip ekonomi, yaitu dengan pengorbanan sekecil-kecilnya dan mendapatkan keuntungan sebesar-besarnya sehingga tujuan kredit yang utama adalah untuk mendapatkan keuntungan. Di Indonesia yang sedang membangun maka tujuan kredit adalah untuk mensukseskan pembangunan, oleh sebab itu ada beberapa program kredit berupa bantuan dari pemerintah dengan tujuan untuk membantu masyarakat. Setiap kredit yang diberikan oleh kreditur pasti memiliki tujuan dan biasanya tujuan tersebut dicantumkan sebagai nama kredit (Wahyuni, 2018: 55), seperti contohnya kredit usaha mikro yang bertujuan untuk mengembangkan usaha masyarakat untuk meningkatkan taraf kehidupan rakyat. Sedangkan menurut Kasmir tujuan pemberian kredit selain untuk mencari keuntungan juga untuk membantu nasabah yang sedang membutuhkan dana, serta membantu pemerintah dalam penerimaan pajak, membuka kesempatan kerja, dan meningkatkan barang jasa dimasyarakat (Kamsir, 1997: 96). Pasal 1 Ayat 8 Peraturan Bank Indonesia Nomor 14/22/PBI/2012 Tentang Pemberian Kredit Atau Pembiayaan Oleh Bank Umum Dan 
Bantuan Teknis Dalam Rangka Pengembangan Usaha Mikro, Kecil, Dan Menengah bahwa Kredit atau pembiayaan usaha mikro, kecil, dan menengah yang selanjutnya disebut kredit atau pembiayaan UMKM adalah kredit atau pembiayaan yang diberikan kepada pelaku usaha yang memenuhi kriteria.

Pada pemberian kredit sumber dana yang dipinjamkan oleh pihak bank bukan hanya berasal dari dana modal bank itu sendiri namun juga menggunakan dana yang berasal dari simpanan nasabahnya, inilah bentuk kongkrit dari menghimpun dana dan menyalurkannya kembali dalam bentuk kredit (Simorangkir, 1989). Terkait menggunakan dana yang berasal dari nasabah maka akan semakin besar tanggung jawab bank dalam mempertanggung jawabkan kredit yang diberikannya, jika terdapat suatu kredit dengan jumlah yang sangat besar dan ditemukan masalah pada suatu hari seperti contohnya kredit tidak dibayarkan tepat waktu maka dapat diindikasikan sebagai kredit bermasalah (Simorangkir, 1989). Pasal 1 ayat 6 Peraturan Bank Indonesia Nomor 11/25/PBI/2009 Tentang Perubahan Atas Peraturan Bank Indonesia Nomor 5/8/PBI/2003 Tentang Penerapan Manajemen Resiko Bagi Bank Umum Kredit bermasalah merupakan resiko yang dapat ditanggung oleh perbankan, dan juga sangat dihindari oleh bank itu sendiri. Risiko kredit adalah risiko akibat kegagalan debitur dan/atau pihak lain dalam memenuhi kewajiban kepada bank.

Pada saat menerapkan prinsip kehati-hatian guna meminimalisir kerugian yang disebabkan oleh kredit bermasalah maka pihak Bank Mandiri Cabang Jember melaksanakan prinsip 5C yang salah satunya adalah prinsip character. Guna mengetahui character calon nasabah apakah layak atau tidak untuk diberikan kredit maka hal itu dapat diwujudkan dengan cara melakukan survei lapangan atau dalam bahasa lain bahwa pihak bank akan mendatangi rumah calon debitur secara langsung. Survei lapangan dilakukan untuk mencocokan data yang ada dengan keterangan calon debitur, selain itu pihak bank juga akan melakukan wawancara serta melalui wawancara tersebut petugas bank dan calon debitur akan melakukan obrolan sehingga petugas bank dapat membaca character calon debitur. Terkait itu analisis character sangat penting untuk dilakukan oleh pihak bank manakala akan memberikan kredit baik kepada perseorangan maupun kelompok, untuk mendapatkan kredit maka pihak bank harus melakukan analisis dengan beberapa tahapan salah satu tahapannya adalah menganalisis character calon debitur. Adapun alur yang harus dilakukan untuk mengetahui character calon debitur sebagai berikut (Wawancara: Maya dan Riska, 6 Januari 2020):

\section{Tabel 1.}

\section{Skema Pemberian Kredit Pada Bank Mandiri Cabang Jember}

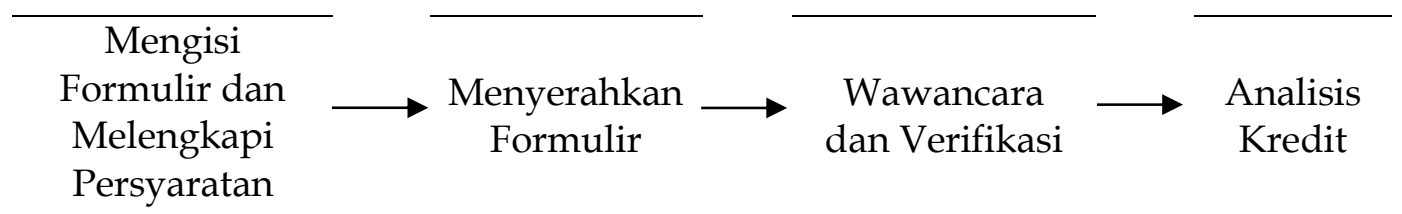

Sumber : Bank Mandiri Cabang Jember, diolah pada tanggal 25 Maret 2020

1. Mengisi Formulir dan Melengkapi Persyaratan

Tahap awal ketika seseorang akan mengajukan kredit adalah dengan mengajukan permohonan kredit secara tertulis, karena pengajuan kredit kepada pihak bank harus didasari dengan permohonan tertulis dari calon debitur (Guntara, 2017: 35). Calon debitur yang akan mengajukan kredit diarahkan kepada bagian Mikro Kredit Sales, kemudian calon debitur akan dipandu untuk mengisi formulir. Selain mengisi formulir, calon 
debitur juga diminta untuk melengkapi persyaratan yang diperlukan. Berikut adalah persyaratan yang diperlukan oleh calon debitur antara lain:
a. Foto copy KTP suami-istri;
b. Kartu keluarga;
c. Surat nikah;
d. Foto copy jaminan (BPKB/Akta Jual Beli/Akta Hibah/Sertifikat);
e. Foto copy surat keterangan usaha;
f. Nota pembayaran.

2. Menyerahkan Formulir

Setelah calon debitur mengisi formulir, kemudian formulir tersebut harus diserahkan kembali kepada petugas bank yang bersangkutan yaitu pada bagian mikro kredit sales. Formulir dan persyaratan yang diserahkan oleh calon debitur akan diperiksa mengenai kelengkapannya. Setelah melakukan penelitian kelengkapan formulir dan juga persyaratan maka petugas akan meregister data pemohon kedalam file informasi pemohon. Petugas dapat melakukan verifikasi dan wawancara, wawancara dilakukan oleh petugas dengan cara mensurvei langsung ke lapangan ataupun dengan memanggil calon debitur ke kantor Bank Mandiri Cabang Jember.

3. Verifikasi dan Wawancara

Pada tahap ini petugas akan melakukan verifikasi terhadap kelengkapan dan legalitas dokumen, verifikasi juga digunakan untuk mengetahui apakah dokumen sudah lengkap sesuai persyaratan (Siregar, 2018: 36). Saat data tidak lengkap maka calon debitur akan diminta untuk melengkapinya. Verifikasi dilakukan oleh petugas bank dengan tujuan untuk mencocokkan data dan selain itu verifikasi dilakukan oleh petugas dengan cara melakukan survei serta cek lingkungan secara langsung ke lapangan, bentuk survei serta cek lingkungan secara langsung ke lapangan dilakukan oleh petugas dengan melakukan On The Spot cheking dan trade cheking sebagai bentuk untuk mencari informasi mengenai calon debitur.

\section{a. On The Spot Checking (OTS)}

OTS dilakukan dengan cara mengunjungi secara langsung tempat usaha calon debitur, kunjungan ini bertujuan untuk mengecek kebenaran dokumen yang ada dengan kondisi yang sebenarnya dengan melihat tempat usaha serta lebih menggali aktivitas usaha debitur. OTS dilakukan untuk mendapatkan gambaran mengenai usaha calon debitur untuk dilakukannya analisis usaha.

\section{b. BI (Bank Indonesia) Checking}

BI Checking dilakukan untuk mengetahui riwayat pembiayaan yang pernah diterima serta status nasabah yang telah ditetapkan oleh BI, pengecekan ini memiliki tujuan agar dapat mengetahui rating nasabah tersebut baik atau (Syafik, Mohammad \& Murni, 2019: 269). Dalam tahap ini ada peran dari Otoritas Jasa Keuangan (OJK), peran tersebut dalam bentuk memberikan informasi mengenai data keuangan dan termasuk riwayat pembiayaan nasabah. Bank Indonesia itu sendiri merupakan bank sentral yang melakukan pengawasan terhadap setiap kegiatan bank, oleh sebab itu biasanya apabila terdapat nasabah yang memiliki riwayat buruk terhadap pembiayaan maka akan masuk kedalam daftar hitam Bank Indonesia. Saat seorang nasabah telah masuk kedalam daftar hitam maka akan sulit untuk melakukan kegiatan yang berhubungan dengan perbankan seperti halnya membuka tabungan. BI Checking dilakukan untuk mendapatkan 
informasi mengenai calon debitur terutama dalam hal riwayat pembiayaan, informasi ini didapatkan dari Otoritas Jasa Keuangan (OJK). Saat calon debitur memiliki riwayat yang tidak baik maka kredit tidak dapat diterima.

\section{c. Trade Checking}

Trade Checking dilakukan untuk menilai calon debitur dalam cara ia mejalankan usahanya, hubungan dagang yang telah dilakukan oleh calon debitur, serta cara manajemen usaha yang dilakukannya (Anjani, 2018: 43). Pada praktiknya Trade Checking dilakukan bersamaan dengan On The Spot Checking.

Setelah melakukan verifikasi maka selanjutnya akan dilakukan wawancara yang merupakan tahap penyelidikan secara langsung kepada calon debitur, Wawancara adalah salah satu cara untuk mengetahui character dari seseorang, biasanya petugas akan melakukan wawancara dengan berbicara santai mengenai kredit yang akan diajukan dan mungkin juga dapat membicarakan hal lain seperti kehidupan pribadi calon debitur(Anjani, 2018: 43). Tujuan dari wawancara adalah guna mencocokan berkas yaitu identitas, agunan, usaha, dan character. Petugas akan memverifikasi berkas - berkas seperti sertifikat agunan dengan mengujungi agunan tersebut, surat keterangan usaha, dan identitas. Petugas juga menanyakan kredit yang diajukan akan diperuntukan untuk kegiatan apa, selama melakukan pertanyaan petugas juga dapat membaca character melalui sikap dan cara menjawab calon debitur.

Terkait nasabah lama penilaian dapat dilihat dari riwayat pembiayaan yang pernah diberikan, apabila pada riwayat diindikasikan baik maka dapat disimpulkan penilaian kepada character nasabah juga baik (Syafik, Mohammad \& Murni, 2019: 269). Pada praktiknya terkadang petugas menemukan bahwa nasabah yang telah lama mendapat pembiayaan melakukan manipulasi data, biasanya manipulasi dilakukan pada dokumen yang berkaitan dengan keuangan. Pada kenyataannya usaha yang dilakukan nasabah tersebut tengah mengalami keterpurukan, namun supaya nasabah tersebut mendapat pembiayaan lagi oleh pihak bank maka dokumen keuangan dimanipulasi seakan baik-baik saja.

Pihak bank mandiri cabang Jember juga menyatakan, bahwa penerapan prinsip character juga digunakan untuk mewaspadai apabila terdapat calon debitur yang meminta pihak bank untuk mempercepat pencairan dana karena biasanya calon debitur tersebut tengah dililit hutang sehingga dana kredit diperuntukan untuk membayar hutang. Dana yang diberikan juga dapat disalahgunakan dengan cara dipergunakan tidak semestinya, maka dari itu analisa character sangat penting untuk dilakukan guna mencegah hal yang tidak diinginkan (Guntara, 2017: 41). Selain melakukan kunjungan langsung kepada calon debitur, petugas juga akan melakukan cek lingkungan dengan cara bertanya kepada tetangga calon debitur, pertanyaan yang diajukan juga tidak jauh dari pertanyaan yang diberikan kepada calon debitur yang tujuannya adalah untuk mencocokan jawaban yang ada.

4. Analisis Kredit

Tahap selanjutnya setelah melakukan wawancara dan verifikasi maka pihak bank akan melakukan analisa terhadap permohonan kredit yang diajukan oleh calon debitur, analisa dilakukan untuk mengetahui layak ataukah tidak calon debitur mendapatkan pembiayaan dan selain itu juga untuk mengetahui berapa kredit yang dapat diberikan kepada calon debitur tersebut. Analisis kredit adalah suatu proses analisis yang menggunakan pendekatan-pendekatan dan rasio-rasio keuangan untuk menentukan 
kebutuhan kredit yang wajar (Wahyuni, 2018: 60). Tujuan dari analisis kredit untuk memperoleh keyakinan apakah calon debitur memiliki kemampuan dan juga kemauan untuk memenuhi kewajibannya kepada pihak bank dalam membayarkan pinjamannya guna menghindari kredit macet yang dapat menyebabkan kerugian bagi pihak bank (Siregar, 2018: 32). Analisis kredit dilakukan dengan mengecek data copy-an dengan data aslinya guna mengetahui keaslian surat tersebut serta informasi keuangan nasabah, KTP calon debitur harus sesuai dengan data yang terdapat pada Dispendukcapil Kabupaten Jember, dan nomor NPWP harus valid. Pada tahap analisis ada dua jenis data informasi yang akan di input yaitu data kualitatif dan data kuantitatif. Data kualitatif menyangkut karakter, lokasi usaha, kepemilikan usaha calon debitur sedangkan data kuantitatif lebih mengarah kepada informasi keuangan.

Guna dapat menentukan besarnya angsuran calon debitur pihak Bank Mandiri Cabang Jember memiliki sistem tersendiri yaitu LOS yang merupakan singkatan dari Loan Origination System. Pada sistem LOS informasi keuangan hasil laba usaha calon debitur akan dimasukan kedalam sistem tersebut serta dalam sistem tersebut akan dilakukan perhitungan secara tersistem yang kemudian akan memunculkan review mengenai besaran angsuran yang sanggup dibayarkan oleh calon debitur. Saat menghitung besaran angsuran calon debitur, sistim LOS tidak mengambil 100\% laba usaha calon debitur namun hanya akan mengambil $80 \%$ dari laba usaha tersebut. Apabila laba calon debitur 10 juta perbulan maka sisitim LOS tidak akan menghitung 10 juta melainkan $80 \%$ dari 10 juta tersebut. Terkait untuk menghitung besaran angusran calon nasabah adalah dengan perhitungan 35\% dari 80\% laba usaha tersebut. Sehingga apabila $80 \%$ dari 10 juta adalah 8 juta, maka besaran angsurannya adalah 35\% dari 8 juta tersebut dan akan menemukan jumlah 2,8 juta. Maka kesanggupan calon debitur untuk membayar angsuran adalah 2,8 juta maka besaran kredit yang akan diberikan disesuaikan dengan perhitungan ini.

Analisis character calon debitur dilakukan seperti yang telah dijelaskan sebelumnya, untuk mengetahui character calon debitur dilakukan dengan cara melakukan wawancara serta verifikasi data yang ada dan juga dilakukan analisis data dengan tujuan untuk mendapatkan keyakinan layak ataukah tidak calon debitur mendapatkan pembiayaan selain itu juga untuk mengetahui kemampuan calon debitur dalam membayarkan kredit. Namun sebelum pada tahap tersebut maka terlebih dahulu calon debitur harus mengisi formulir, menyerahkan formulir dan melengkapi persyaratan, kemudian setelah itu dapat dilakukannya tahap wawancara dan verifikasi. Tahap ini harus dilakukan dengan benar dan dasar jujur dari calon nasabah maupun petugas dari pihak bank. Pada proses ini seringkali terjadi manipulasi dokumen dari calon nasabah yang tidak memiliki character yang baik, selain itu dari sisi petugas bank juga seringkali didapati ada yang menerima suap dengan tujuan untuk menutupi character ataupun kecurangan yang dialakukan oleh calon nasabah.

Setelah tahap verifikasi dan wawancara untuk dapat menilai character calon debitur, maka tahap selanjutnya dalam analisis pemberian kredit sebagai berikut : 


\section{Tabel 2.}

\section{Skema Pemberian Kredit Pada Bank Mandiri Cabang Jember}

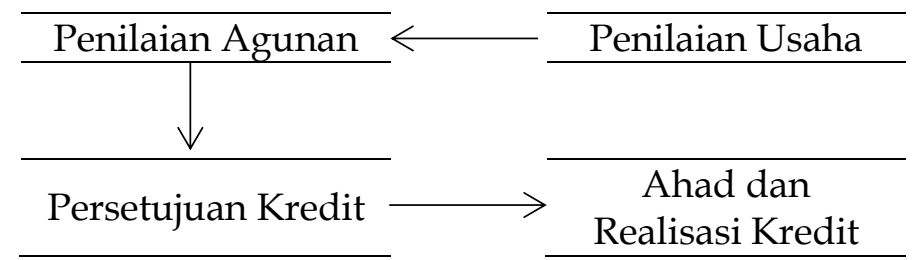

Sumber : Bank Mandiri Cabang Jember, diolah pada tanggal 25 Maret 2020

5. Penilaian Usaha

Pada tahap ini pihak bank akan melakukan penilaian terhadap usaha yang dijalankan oleh calon debitur, berdasarkan hasil verifikasi melalui OTS dan trade checking petugas bank akan melakukan segmentasi usaha yaitu melihat jenis usaha yang dijalankan oleh calon debitur apakah tergolong usaha jasa ataukah usaha dagang. Selain segmentasi usaha, petugas juga akan melihat kapasitas usaha tersebut, usaha yang dijalankan dilihat dari besarnya usaha dan akan disamakan dengan nilai kredit yang diajukan oleh calon debitur. Saat dinilai usaha yang dijalankan kecil dan tidak sebanding dengan jumlah kredit yang diajukan maka pihak bank akan menurunkan limit kredit yang akan diberikan.

6. Penilaian Agunan

Agunan atau collateral merupakan suatu hal yang digunakan sebagai sumber pengembalian kredit, pihak bank akan melakukan evaluasi terhadap agunan calon debitur untuk mengetahui kecukupan nilai dari agunan tersebut (Wahyuni, 2018: 61). Agunan dapat berupa objek yang dibiayai dengan kredit, sesuai dengan penjelasan Pasal 8 Undang-undang Nomor 10 Tahun 1998 Tentang Perubahan Atas Undangundang Nomor 7 Tahun 1992 Tentang Perbankan bahwa agunan hanya dapat berupa barang atau proyek yang dibiayai dengan kredit yang bersangkutan dan bank tidak memiliki kewajiban untuk meminta agunan berupa barang diluar objek yang dibiayai.

Suatu objek yang akan dijadikan agunan harus memiliki kriteria antara lain memiliki nilai ekonomis, kepemilikan dapat dipindah tangankan, mempunyai nilai hukum berdasarkan kekuatan Undang-undang (Hasibuan, 2009: 107). Saat penilaian agunan pihak bank akan menilai apakah agunan setara dengan limit kredit yang diajukan, apabila agunan tidak memiliki nilai yang setara dengan kredit yang diajukan maka nilai limit kredit yang akan diberikan kepada calon debitur akan diturunkan. Berikut merupakan beberapa objek agunan yang dapat diterima oleh pihak bank:
a. BPKP;
b. Kendaraan;
c. Sertifikat kepemilikan;
d. Akte jual beli;
e. Akte hibah;
f. Akte pembagian hak bersama. 


\section{Persetujuan Kredit}

Setelah melalui serangkaian tahap analisis dan informasi mengenai karakter, informasi keuangan, kelangsungan usaha, agunan calon debitur telah lengkap dan mendapat persetujuan pimpinan bank untuk menyetujui pengajuan kredit calon debitur maka kemudian pimpinan bank akan menghubungi pihak mikro sales kredit. Setelah dihubungi oleh pimpinan maka selanjutnya tim mikro sales kredit akan menghubungi calon debitur untuk diberitahukan bahwasannya kredit yang diajukan disetujui oleh pihak bank. Calon debitur akan dipanggil ke kantor Bank Mandiri Cabang Jember untuk dilakukannya akad dan realisasi kredit.

8. Akad dan Realisasi Kredit

Setelah calon debitur dihubungi oleh pihak bank bahwa kredit yang diajukan diterima maka selanjutnya calon debitur akan melakukan akad kredit. Sebelum melakukan akad maka terlebih dahulu calon debitur akan diberikan beberapa penjelasan antara lain mengenai limit kredit yang diberikan, suku bunga, jangka waktu tempo lunas, jangka waktu pembayaran, dan biaya-biaya administrasi lainnya. Terkait beberapa hal tersebut telah dijelaskan dan calon debitur menyetujuinya, maka selanjutkan pihak bank dan calon debitur melakukan akad kredit. Akad kredit dilakukan dengan menandatangani surat perjanjian kredit, BAP serah terima, surat kuasa, surat kuasa menjual agunan, surat pernyataan, dan jadwal angsuran. Terkait telah dilakukannya akad dengan menandatangani beberapa dokumen maka selanjutnya dokumen tersebut akan diproses kembali selama kurang lebih 2 jam untuk aktifasi rekening guna pencairan dana kredit.

Guna dapat memberikan kredit, pihak bank harus melakukan serangkaian analisis yang bertujuan untuk mengetahui apakah calon debitur layak atau tidak menerima pembiayaan dari pihak bank. Guna dapat meminimalisir kerugian bank maka pihak Bank Mandiri Cabang menerapkan prinsip 5C terutama prinsip character sebagai wujud dari prinsip kehati-hatian. Analisis character merupakan unsur yang penting untuk dilakukan, character calon debitur adalah salah satu kunci yang paling penting karena sebagai penentu apakah calon debitur memiliki kemauan untuk membayar pinjaman yang diajukannya. Pada tahap analisis character petugas menemukan bahwa calon debitur berkepribadian tidak baik atau memiliki rekam jejak yang tidak baik pula maka kemungkinan besar permohonan kreditnya tidak dapat diterima oleh pihak bank.

Pihak bank sendiri juga harus berhati-hati dan lebih mewaspadai ketika hendak memberikan kredit kepada calon debitur, ketika pihak bank kurang selektif dalam menganalisis calon debitur maka dikemudian hari bank tersebut bisa mendapat resiko kredit tidak kembali pada waktunya. Resiko kredit tidak kembali secara tepat waktu merupakan resiko yang dihindari oleh pihak bank, maka oleh sebab itu diterapkannya serangkaian analisis terutama analisis character. Terkait dilakukannya analisis kredit terutama dengan menganalisis character calon debitur pada Bank Mandiri Cabang Jember terbukti dapat meminimalisir kredit bermasalah yang dapat menyebabkan kerugian bagi pihak bank, akan tetapi penerapan prinsip character tidak semerta-merta menghilangkan adanya resiko itu sendiri sebab resiko perbankan jelas akan tetap ada.

\section{Kesimpulan}

Adapun kesimpulan yang dapat diambil dari pembahasan bahwa penerapan prinsip character dalam pemberian kredit usaha mikro pada Bank Mandiri Cabang Jember guna 
meminimalkan kerugian bank dilakukan dengan 3 langkah yaitu verifikasi yang dilakukan dengan tujuan mencocokkan data yang ada, wawancara yang dilakukan dengan tujuan mencocokan berkas yaitu identitas, agunan, usaha, dan character dengan kondisi sebenarnya, serta analisis data yang dialkukan dengan tujuan untuk mendapatkan keyakinan apakah debitur sanggup mengembalikan kredit.

\section{Daftar Referensi}

\section{Jurnal}

Sari, G. N. (2013). Faktor-faktor yang Mempengaruhi Penyaluran Kredit Bank Umum di Indonesia (Periode 2008.1-2012.2). Jurnal EMBA, 1(3), 931-941.

Syafik, Mohammad \& Murni, T. S. (2019). Analisis Penerapan Prinsip 7C Dalam Meminimalisi Resiko Pembiayan Pada PT. BPR Rukun Karya Sari Kedungpiring. Jurnal Ilmiah Akuntansi Peradaban, 5(2), 259-278. https://doi.org/10.24252/jiap.v5i2.11888

Wardani, P. D. K., Rudy, D. Gde., Wiryawan, I. W. (2013). Implementasi Prinsip Kehatihatian Dalam Pemberian Kredit Pada PT BPR Sinar Putera Mas. Kertha Semaya, 1(8), 1 13. https://ojs.unud.ac.id/index.php/kerthasemaya/article/view/42079

Wilardjo, S. B. (2014). Pengertian, Peranan dan Perkembangan Bank Syari'ah di Indonesia. Value Added, 2(1), 1-10.

Buku

Abdullah, Thamrin \& Tantri, F. (2012). Bank dan Lembaga Keuangan. Jakarta: Raja Grafindo Persada.

Djumhana, M. (1993). Hukum Perbankan Indonesia. Bandung: Citra Aditya Bakti.

Hasibuan, M. S. P. (2009). Dasar-Dasar Perbankan. Jakarta: Sinar Grafika Offset.

Jusuf, J. (1995). Analisis Kredit Untuk Account Officer. Jakarta: Gramedia Pustaka Utama.

Kamsir. (1997). Bank dan Lembaga Keuangan lainnya. Jakarta: Raja Grafindo Persada.

Mgs. The'Aman, E. P. (1989). Kredi Perbankan Suatu Tujuan Yuridis. Yogyakarta: Liberty.

Simorangkir, O. P. (1989). Kamus Perbankan. Jakarta: Bina Aksara.

Supramono, G. (1996). Perbankan dan Masalah Kredit. Jakarta: Djambatan.

Suyatno, T. (1990). Dasar-Dasar Perkreditan. Jakarta: Gramedia Pustaka Utama.

Usman, R. (2012). Aspek Hukum Perbankan Syariah di Indonesia. Jakarta: Sinar Grafika.

Yuspin, W. (2016). Aspek Hukum dan Kelembagaan Perbankan Syariah. Yogyakarta: Genta Publishing.

Skripsi, Tesis

Anjani, S. (2018). Penerapan Prinsip 5C Dalam Pemberian Kredit Sebagai Pencegahan Kredit Bermasalah. Skripsi, Universitas Sumatera Utara.

Guntara, A. (2017). Pnerapan Prinsip 5C Sebagai Upaya Perlindungan Terhadap Bank Dalam Menyalurkan Kredit. Skripsi, Universitas Udayana.

Pratama, B. A. (2010). Analisis Faktor-Faktor Yang Mempengaruhi Kebijakan Penyaluran Kredit Perbankan. Tesis, Universitas Diponegoro. 
Siregar, E. N. (2018). Analisa Penerapan Prinsip 5C (Character, Capacity, Collateral, Capital, Condition Of Economy) Pada PT. Bank Sumut KCP USU. Skripsi, Universitas Sumatera Utara.

Wahyuni, N. (2018). Penerapan Prinsip 5C Dalam pemberian Kredit Sebagai Perlindungan Bank. Skripsi, Universitas Kediri.

Yunita, N. P. (2019). Perlindungan Hukum Nasabah Beritikad Baik Terhadap Proses Lelang Jaminan Hak Milik Atas Tanah Dalam Perjanjian Kredit (Tinjauan Yuridis Terhadap Putusan Mahkamah Agung Republik Indonesia Nomor 283 K/Pdt.Sus-BPSK/2018). Skripsi, Universitas Jember. 